\title{
Geochemistry of the mantle beneath the Rodriguez Triple Junction and the South-East Indian Ridge*
}

Rodriguez Triple Junction Southeast Indian Ridge

Basalt

Isotopic composition Rare-earth elements

Point triple de Rodriguez Dorsale est-indienne Basalte Composition isotopique Terres rares

\author{
A. MICHARD ${ }^{a}$, R. MONTIGNY ${ }^{b}$, R. SCHLICH ${ }^{b}$ \\ ${ }^{a}$ Centre de Recherches Pétrographiques et Géochimiques, B.P. 220, 54501 Vandœuvre-lès- \\ Nancy (France) \\ b Institut de Physique du Globe de Strasbourg, 5, rue Descartes, 68084 Strasbourg Cedex \\ (France)
}

\footnotetext{
"This article has been previously published in : Earth and Planetary Science Letters, 78 (1986) 104-114. Elsevier Science Publishers B.V., Amsterdam - Printed in The Netherlands
}

ABSTRACT
Rare earth element abundances and $\mathrm{Sr}, \mathrm{Nd}, \mathrm{Pb}$ isotope compositions have been measured on zero-age dredge sample from the Rodriguez Triple Junction (RTJ) and the South-East Indian Ridge (SEIR). Along the SEIR, the geochemical "halo" of the St. Paul hot spot has a half-width of about $400 \mathrm{~km}$ and the data may be fairly well accounted for by a binary mixing between an Indian MORB-type component $\left({ }^{87} \mathrm{Sr} /{ }^{86} \mathrm{Sr}=0.7028,{ }^{143} \mathrm{Nd} /{ }^{144} \mathrm{Nd}=\right.$ $\left.0.51304,{ }^{206} \mathrm{~Pb} /{ }^{204} \mathrm{~Pb}=17.8\right)$ and the plume-type St. Paul component $(0.7036,0.5129$, and 18.7 respectively). The alignment of the lead isotope data is particularly good with an apparent age of $1.95 \pm 0.13 \mathrm{Ga}$ and $\mathrm{Th} / \mathrm{U}$ source value of 3.94. One sample dredged on the ridge $60 \mathrm{~km}$ southeast of St. Paul bears a definite Kerguelen isotopic signature.

The RTJ has distinctive geochemical properties which contrast with those of the adjacent ridge segments. Low ${ }^{206} \mathrm{~Pb} /{ }^{204} \mathrm{~Pb}$ ratios which plots to the left of the geochron, rather high ${ }^{208} \mathrm{~Pb} /{ }^{204} \mathrm{~Pb}$ and ${ }^{87 \mathrm{Sr}} /{ }^{86} \mathrm{Sr}$ ratios $(17.4,37.4$, and 0.7031 respectively), a striking isotopic homogeneity, and variable LREE/HREE fractionation with $(\mathrm{La} / \mathrm{Sm})_{\mathrm{N}}=0.3-0.8$ make this triple junction an anomalous site.

The geochemical properties of the Indian Ocean basalts have been examined using a threecomponent mantle model involving (a) normal MORB-type source though to represent the depleted upper mantle matrix, (b) an OIB-type source of uncertain parentage (recycled oceanic crust ?), and (c) a component with low $\mu$, low $\mathrm{Sm} / \mathrm{Nd}$, high $\mathrm{Rb} / \mathrm{Sr}$ (time-average value) which is tentatively assigned to ancient hydrothermal and abyssal sediments recycled in the mantle. The high ${ }^{208} \mathrm{~Pb} /{ }^{204} \mathrm{~Pb}$ and ${ }^{87} \mathrm{Sr} /{ }^{86} \mathrm{Sr}$ ratios typical of the Dupal anomaly are likely due to the widespread distribution of this latter component in the basalt source from this area, including that for MORBs.

Oceanologica Acta, 1990. Volume spécial 10, Actes du Colloque Tour du Monde Jean Charcot, 2-3 mars 1989, Paris. 143-152.

RÉSUMÉ

Géochimie du manteau au point triple de Rodriguez et à la dorsale est-indienne

Nous avons mesuré les concentrations en terres rares et les compositions isotopiques de $\mathrm{Pb}, \mathrm{Nd}$ et $\mathrm{Sr}$ de basaltes d'âge zéro dragués sur le point triple de Rodriguez et la dorsale 
est-indienne. Le long de la dorsale est-indienne, le halo géochimique du panache de SaintPaul a une demi-longueur d'environ $400 \mathrm{~km}$, et les donnée s'expliquent aisément par un mélange binaire entre un composant type basalte de l'Océan Indien $\left({ }^{87} \mathrm{Sr} /{ }^{\beta 6} \mathrm{Sr}=0,7028\right.$, $\left.{ }^{143} \mathrm{Nd} /{ }^{144} \mathrm{Nd}=0,51304,{ }^{206} \mathrm{~Pb} /{ }^{204} \mathrm{~Pb}=17,8\right)$, et un composant Saint-Paul de type panache $(0,7036,0,5129$ et 18,7 respectivement). L'alignement des données dans les diagrammes $\mathrm{Pb}-\mathrm{Pb}$ est particulièrement satisfaisant. Il indique un âge de $1,95 \pm 0,13 \mathrm{Ga}$ et une valeur $\mathrm{Th} / \mathrm{U}$ pour la source de 3,94 . Un échantillon dragué sur la dorsale à $60 \mathrm{~km}$ au sud-est de Saint-Paul a une signature isotopique de type Kerguelen.

Le point triple de Rodriguez a des propriétés géochimiques caractéristiques, qui contrastent avec celles des dorsales adjacentes. Ainsi de bas rapports ${ }^{206} \mathrm{~Pb} /{ }^{204} \mathrm{~Pb}$, situés à gauche de la géochrone, de hauts rapports ${ }^{208} \mathrm{~Pb} /{ }^{204} \mathrm{~Pb}$ et ${ }^{87} \mathrm{Sr} /{ }^{96} \mathrm{Sr}(17,4,37,4$ et 0,7031 respectivement), une homogénéité isotopique remarquable et des fractionnements terres rares légères/terres rares lourdes avec des rapports $(\mathrm{La} / \mathrm{Sm}) \mathrm{N}=0,3-0,8$, font de ce point triple un site anormal. Nous proposons un modèle de manteau à trois composants pour expliquer les propriétés géochimiques des basaltes de l'Océan Indien : a) une source basalte des dorsales (MORB); b) une source basalte alcalin (OIB), comportant éventuellement de la croûte océanique recyclée; c) un composant à $\mu$ faible, à bas rapports $\mathrm{Sm} / \mathrm{Nd}$ et haut rapport $\mathrm{Rb} / \mathrm{Sr}$, que l'on suppose être d'anciens sédiments abyssaux d'origine hydrothermale recyclés dans le manteau. Les hauts rapports ${ }^{208} \mathrm{~Pb} /{ }^{204} \mathrm{~Pb}$ et ${ }^{87} \mathrm{Sr} /{ }^{86} \mathrm{Sr}$ caractéristiques de l'anomalie Dupal, sont probablement le fait de la présence de ce composant dans les sources des basaltes de cette région, et notamment dans celle des basaltes des dorsales (MORB).

Oceanologica Acta, 1990. Volume spécial 10, Actes du Colloque Tour du Monde Jean Charcot, 2-3 mars 1989, Paris. 143-152.

\section{INTRODUCTION}

Trace element and isotope geochemistry of Mid-Ocean Ridge (MORB) and ocean-island basalts (OIB) have led to diverging models of mantle convection. A first class of models calls for a layered mantle with two independently convecting layers : the upper mantle which two independently convecting layers : the upper mantle which, by extraction of its fertile component now stored in the continental crust, is the source of the MORBs while the more primitive lower mantle is the source of OIB plume material [1,2]. A second class of models [3,4] is based on a whole mantle convection ("plum-pudding mantle") : low degrees of melting involve sparse remnants of ancient lithosphere [5,6], which are more fusible and enriched in incompatible elements; more extensive melting transfers more material from the residual mantle matrix into the melt which has MORB geochemical characteristics. Whereas Davies [7] has convincingly demonstrate that mixed models fit, as well, the geochemical data on oceanic basalts, the identification of chemical heterogeneities in the mantles and the estimation of their extent in space and time are fundamental observations against which any convection model must be tested.

Dupré and Allègre [8] have shown the existence in the Indian and South Atlantic Ocean of a coherent zone in which both MORBs and OIBs have anomalous ${ }^{87} \mathrm{Sr} /{ }^{86} \mathrm{Sr}$, ${ }^{207} \mathrm{~Pb} /{ }^{204} \mathrm{~Pb}$, and ${ }^{208} \mathrm{~Pb} /{ }^{204} \mathrm{~Pb}$, and ${ }^{208} \mathrm{~Pb} /{ }^{204} \mathrm{~Pb}$ ratios compared to the basalts of the main Atlantic/Pacific trend (MAPT). In support of the layered mantle model, they ascribed the source of this anomaly to recent reinjection of sediments into the lower mantle. Hart [9], who coined the term of Dupal anomaly for this zone, suggested that it may predate the events (crust extraction?) which, some $2000 \mathrm{Ma}$ ago on average, produced the present-day observable isotopic heterogeneities in the upper mantle and, to some extent, in the crust. In any case, the question of how such a regional anomaly may remain coherent and persist in the southern hemisphere must be addressed.

The Rodriguez Triple Junction (RTJ), meeting point of three plates (Africa, India, Antarctica), is a major structure of the Indian Ocean. The confluence of three spreading centres, each of different character, marks the site of the triple junction at $25^{\circ} 7^{\prime} \mathrm{S}, 70^{\circ} \mathrm{E}$, this junction is a ridgeridge-ridge type [10]. The evolution of the Indian Ocean suggests that the triple junction has operated since the Upper Cretaceous [11]. The RTJ is a singular point of the Indian Ocean convective system, with a position well within the Dupal anomaly, far from any major ocean island. Its predictably specific thermal and mechanical regime should lead to unusual melting and advection conditions, and provide useful information on the major components of the local upper mantle.

In this work, $\mathrm{Sr}, \mathrm{Nd}$, and $\mathrm{Pb}$ isotopes and $\mathrm{REE}$ concentrations are used to characterize the mantle geochemistry beneath the RTJ, which, in the light of earlier published ${ }^{87} \mathrm{Sr} /{ }^{86} \mathrm{Sr}$ data, has been considered to be enriched in a plume-type component $[12,13]$. In addition, based on samples which are regularly spaced along the South-East Indian Ridge (SEIR) between the RTJ and St. PaulAmsterdam Islands, we have investigated the scale of the influence of this hot spot along the SEIR. 


\section{GEOLOGICAL BACKGROUND AND SAMPLING}

The morphology and the evolution of the RTJ have been summarized by Schlich et al. [14]. The three ridges spread at different half-rates, $2.95,2.73$, and $0.73 \mathrm{~cm} / \mathrm{yr}$ for the SEIR, the Central (CIR), and the South-West Indian Ridge (SWIR), respectively. The samples analysed in this study were collected during two cruises around the RTJ (Rodriguez expedition JC 2-3 of the R/V Jean Charcot, MD 23 of the Marion Dufresne) and another along the SEIR (MD 37) of the Marion Dufresne.

We have analyzed one sample from the triple point sensu stricto and one from each ridge branch taken within $20 \mathrm{~km}$ of the RTJ or less. For the sake of comparison, one sample from the CIR and one from the SWIR dredged at a distance of $400 \mathrm{~km}$ from the RTJ have been included in this study. Another sample from the SWIR was taken $200 \mathrm{~km}$ from the RTJ inside a deep aseismic canyon. Seven samples have been chosen with a rather even spacing along $1800 \mathrm{~km}$ of the SEIR with two of them in the close vicinity of the St. Paul island and one from the island itself. In view of the importance given to the SWIR sample 34-D5 [35] in the forthcoming discussion, an aliquot of the sample has been reanalyzed to achieve a high-accuracy measurement of the ${ }^{143} \mathrm{Nd} /{ }^{144} \mathrm{Nd}$ ratio, and to provide information on its REE content.

The age of samples but one may be considered to be zero. Sample 23-3 has a distance-to-the-ridge age of 670,000 a but the freshness of the glass suggests a younger upper limit of Ca. 20,000 a. All samples but 37-2 and SP1 are fresh and glassy but occasionally contain phenocrysts of olivine, clinopyroxene, and, in the vicinity of the RTJ, abundant plagioclase (Humler and Whitechurch, unpublished data).

Sample location (Fig. 1), depth and distance from the RTJ (not corrected for transform fault offset) are given with results in Table 1.

\section{ANALYTICAL TECHNIQUES}

Millimetre-sized pieces of unaltered basalts were chosen under the binocular microscope. Leaching in $2 \mathrm{~N} \mathrm{HCl}$ for $\mathrm{Sr}$ and $\mathrm{Nd}$ isotope compositions and in $6 \mathrm{~N} \mathrm{HCl}$ for $\mathrm{Pb}$ were performed prior to dissolution. $\mathrm{Sr}$ and $\mathrm{Nd}$ isotope compositions and $\mathrm{Rb}, \mathrm{Sr}$, and $\mathrm{Nd}$ concentrations were de-
Figure 1

Map showing the location of dredge samples around the Rodriguez Triple Junction and along the South-East Indian Ridge.

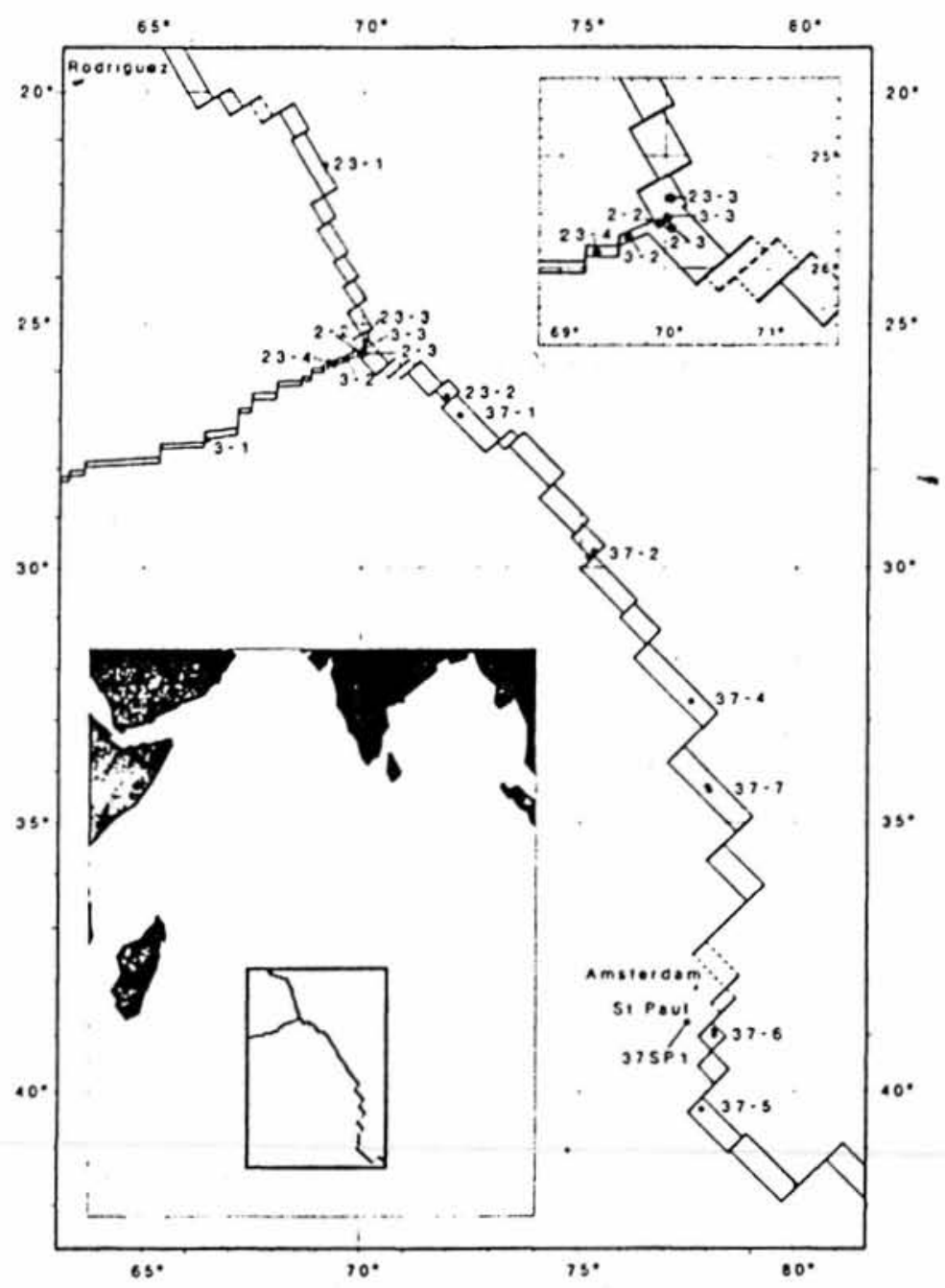




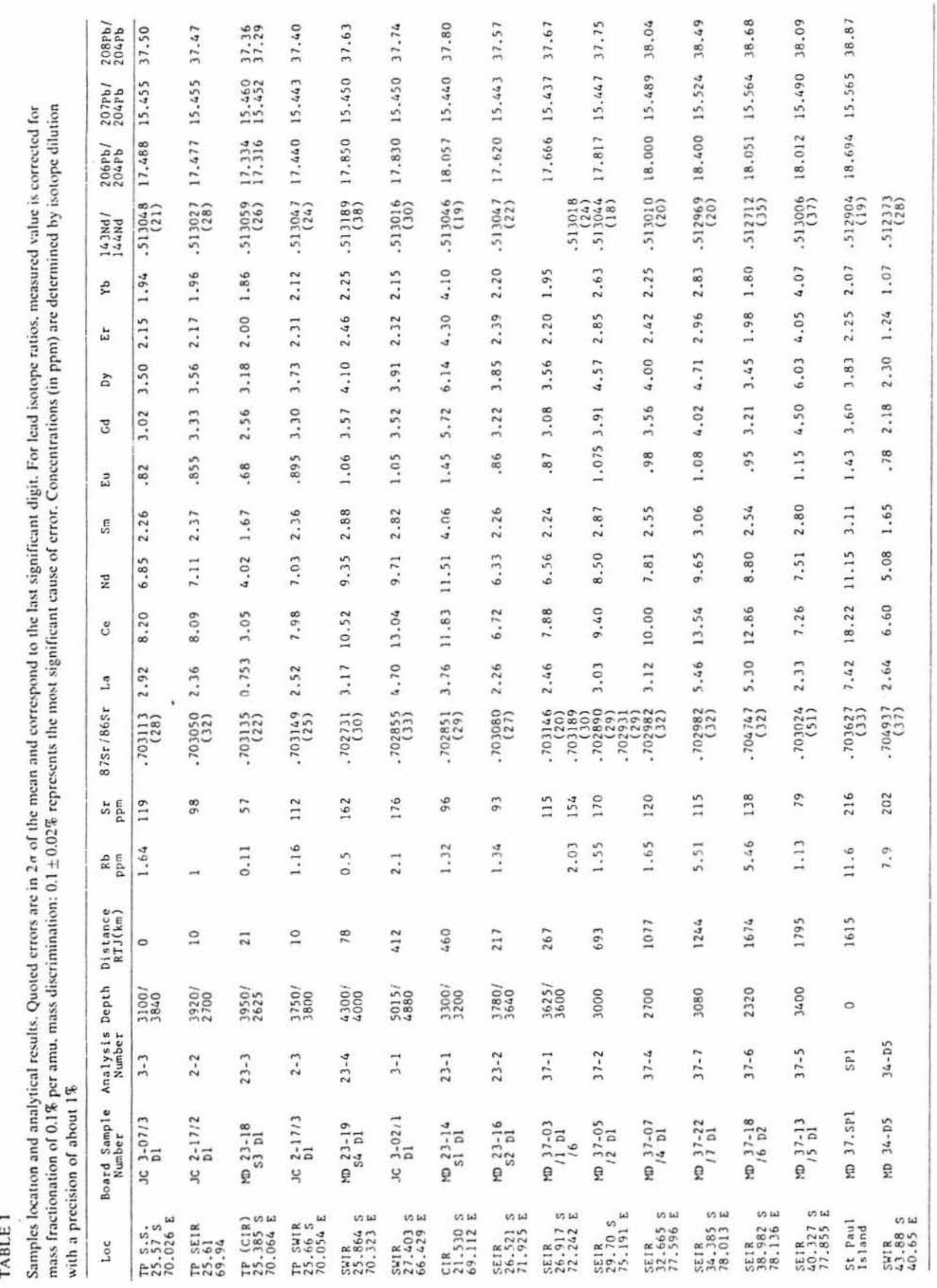


termined on Ca. 100-mg samples using the techniques described by Alibert et al. [16] and Michard et al. [17]. Pb is extracted from $1 \mathrm{~g}$ of rock using the Manhes [18] technique with three steps of $\mathrm{HBr}$ elution on anion exchange resin. The bank for the whole procedure on a l-g sample is less than $0.8 \mathrm{ng}$ of lead.

Isotope standards have been analyzed in the course of this study : ${ }^{87} \mathrm{Sr} /{ }^{86} \mathrm{Sr}=0.707982 \pm 30$ (Eimer and Amend), ${ }^{143} \mathrm{Nd} /{ }^{144} \mathrm{Nd}=0.512639 \pm 15(\mathrm{BCR} 1)$. Replicate analyses of the SRM 981 lead standard compared to the recommended values lead to a discrimination factor olf $1.0 \pm 0.2 \%$ per mass unit.

For REE concentrations, $100-\mathrm{mg}$ sample aliquots, to which a combined spike was added, were dissolved in a HF- $\mathrm{HNO}_{3}-\mathrm{HClO}_{4}$ mixture. A first elution on a 4-cm-long cation exchange column, using $\mathrm{HCl}$ as the eluant, removes major elements and produces a REE-enriched fraction. Then the REE are split in three groups, Lu-Gd, Eu-Ce, $\mathrm{La}$ on a small column of cation exchange resin with 2methyl-lactic acid of drecreasing normality. La is run on the oxide beam with a single W filament, whereas the two heavier groups are analyzed on the metal beams with a double $\mathrm{Re}$ filament.

\section{RESULTS}

In the ${ }^{143} \mathrm{Nd} /{ }^{144} \mathrm{Nd}-{ }^{87} \mathrm{Sr} /{ }^{86} \mathrm{Sr}$ correlation diagram (Fig. 2) nearly all samples plot in the lower part of the MORB field with much less spread than the data of Le Roex et al. [19] for the southern part of the SWIR. The sample taken in an asismic zone of the SWIR plots in the middle of this field. The value of the basalt of St. Paul Island is close to those of Bouvet $[20,21]$. The rock dredged on the ridge near St. Paul falls in the Kerguelen field [22].

In more detail, the samples taken from the vicinity of the RTJ present slightly higher ${ }^{87} \mathrm{Sr} /{ }^{86} \mathrm{Sr}$ ratios than the

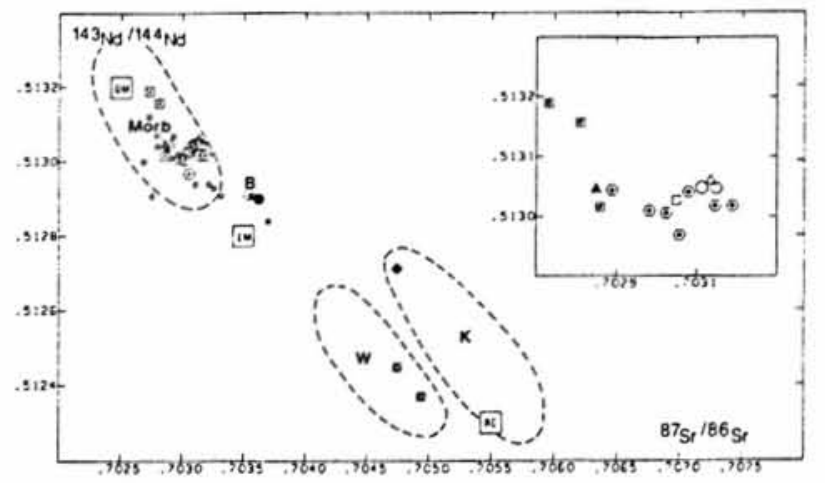

Figure 2

Results on the Indian Ocean basalts in a ${ }^{143} \mathrm{Nd} /{ }^{144} \mathrm{Nd}$ vs. ${ }^{87} \mathrm{Sr} /{ }^{86} \mathrm{Sr}$ diagram. Key for large symbols: $\bigcirc=$ triple junction s.s. South-East Indian Ridge $: O=$ Triple junction s.l., $\odot=$ SEIR; - St. Paul Island. $\checkmark=$ "Kerguelen-type" sample 37-6. South-West Indian Ridge : $\square=$ triple junction s.l. and SWIR; $\mathbb{Q}=34-D 5$ (this work and [IS]). Central Indian Ridge : $\Delta=$ triple junction s.l., $\Delta=C I R$. Smaller symbols are data from the literature $[8,15,19]$. Fields: Morb $=$ Atlantic and Pacific MORBs [13,21,40,56,57]. $W=$ Walvis Ridge [34]. $K=$ Kerguelen $[22,26], B=B$ Bouvet [19]. The large squares are suggested end-members.

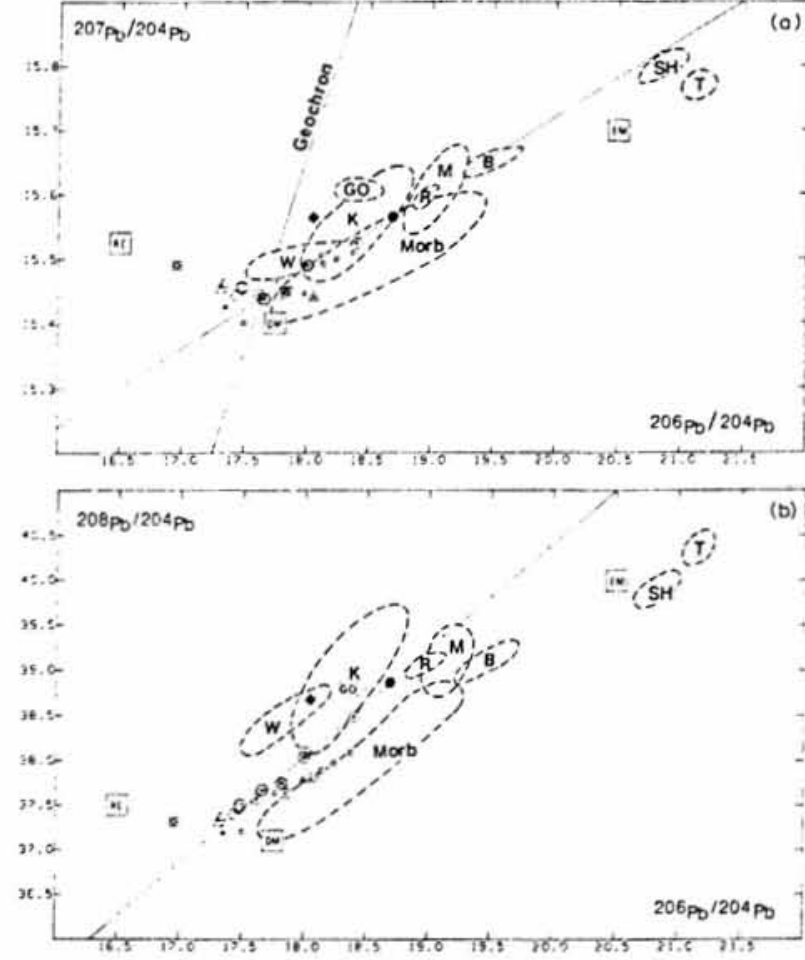

Figure 3

Lead isotope data. For symbols see Fig. 2 : symbol size includes typical error. (a) Regression line drawn from the SEIR and St. Paul data only. The age associated with the slope is $195 \pm 0.13 \mathrm{Ga}$. The RTJ data points fall on the left of both this line and the $4.56 \% \mathrm{Ga}$ geochron. (b) Regression line calculated as in (a) but the RTJ data points now fall on the line. Model Th/U is 3.94. Key for data fields : ST $=$ St. Helena $[38,40]$ $T=$ Tubuaii [39], $M=$ Marquesas [39], $G O=$ Gough [40]. $R=$ Reunion [58].

samples taken $400 \mathrm{~km}$ apart on both the CIR and SWIR. The same comparison holds with the samples from the SWIR analyzed by Hamelin and Allègre [15] and from the Carlsberg Ridge $[8,23,24]$. The field for the SEIR overlap that of the RTJ except for one sample with a slightly lower ${ }^{87} \mathrm{Sr} /{ }^{86}$ ratio. Less variation is observed the ${ }^{143} \mathrm{Nd} /{ }^{144} \mathrm{Nd}$ ratio which is lower than the average $\varepsilon_{\mathrm{Nd}}=$ 8-10 only for the samples near St. Paul.

More variation is observed in the lead isotope diagrams (Fig. 3a and b). The samples from the RTJ s.l. have the lowest ${ }^{206} \mathrm{~Pb} /{ }^{204} \mathrm{~Pb}$ ratio which confirms the existence of very unradiogenic ${ }^{206} \mathrm{~Pb}$ lead in the mantle beneath the Indian Ocean $[8,15,25]$. In comparaison, the ${ }^{207} \mathrm{~Pb} /{ }^{204} \mathrm{~Pb}$ ratios are some $3 \%$ higher than the MAPY. A fairly good linear correlation is observed along therr SEIR which extends from $200 \mathrm{~km}$ away from the RTJ to southwest of St. Paul sample falls on the same alignments, i.e. slightly below the St. Paul and Amsterdam data of Dupré and Allègre [8]. The trend lies above the MAPT more distinclty for ${ }^{208} \mathrm{~Pb} /{ }^{204} \mathrm{~Pb}$ than for ${ }^{207} \mathrm{~Pb} /{ }^{204} \mathrm{~Pb}$ but below the Kerguelen field of Dosso et al. [26]. A noticeable exception is the sample 37-6, which was dredged on a ridge segment between the Ninety-East Ridge and the Kerguelen Plateau and falls close to the Kerguelen field. The slope of the SEIR trends correspond to an age of $1.95 \pm 0.13 \mathrm{Ga}$ and a $\mathrm{K}$ value of 3.94 . 


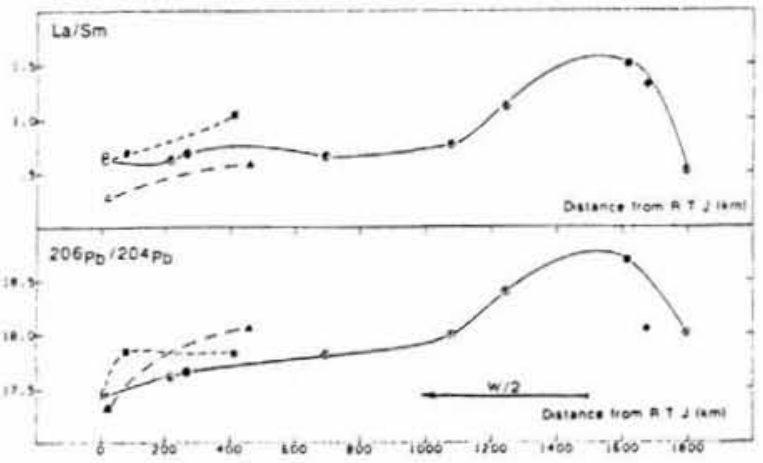

Figure 4

Variations of $(\mathrm{La} / \mathrm{Sm}) \mathrm{v}$ and ${ }^{206} \mathrm{~Pb} /{ }^{204} \mathrm{~Pb}$ with the distance from the triple point. The ${ }^{200} \mathrm{~Pb} / 20 \mathrm{~Pb}$ curve has a pronounced minimum at the RTJ. W/2 is the half-width of the hot-spot halo.

When ${ }^{206} \mathrm{~Pb} /{ }^{204} \mathrm{~Pb}$ and $\mathrm{La} / \mathrm{Sm}$ are reported vs. the distance to the triple junction (Fig. 4), smooth variations are obtained and three main feature become apparent :

- The SEIR presents an isotopic signature distinct from that of the CIR and SWIR for $\mathrm{Pb}$ and to a lesser extent for $\mathrm{Sr}$ (not plotted); previously published datafrom the SWIR [15] are in accord with this finding.

- The RTJ is a low in ${ }^{206} \mathrm{~Pb} /{ }^{204} \mathrm{~Pb}$ and has higher ${ }^{87} \mathrm{Sr} /{ }^{86} \mathrm{Sr}$ ratios than the CIR and the SWIR.

- The anomalous isotopic halo extends over $300-500 \mathrm{~km}$ northwest of the St. Paul hot spot; skewness of the curves is due to the unique "normal" sample 37-5 collected southeast of the island. Undersampling of the SEIR presently makes that estimate somewhat uncertain.

The REE element patterns (Fig. 5) of three samples from the RTJ are barely distinguishable and are typical of normal MORBs with $(\mathrm{La}-\mathrm{Sm})_{\mathrm{N}}=0.6-0.8$. In contrast, the fourth RTJ sample (23-3), taken from the CIR branch, has a pronounced LREE depeltion $(\mathrm{La} / \mathrm{Sm})_{\mathrm{N}}=0.28$ with a nearly similar $\mathrm{Yb}$ concentration. As St. Paul island is approached, the (La.Sm) ratio increases to 1.5. Sample 375 , southeast of St. Paul, has a LREE depeltion similar to that of 23-3 but with concentrations higher by a factor 2-3. Sample 37-6, which presented anomalous isotopic ratios, presents a more enriched REE pattem similar to that of the St. Paul sample. A positive correlation exists between the $\mathrm{Rb} / \mathrm{Sr}$ and the $(\mathrm{La} / \mathrm{Sm})_{\mathrm{N}}$ ratios mostly controlled by the samples from near St. Paul. Sample 34-D5 presents a pattem with flat LREE $(\mathrm{La} / \mathrm{Sm})_{\mathrm{N}}=1$ and a marked positive Eu anomaly likely associated with the large amount of plagioclase phenocrysts observed in this sample.

\section{DISCUSSION}

This study touches on several problems related to the regional geochemistry of the Indian Ocean basalts. Mixing of the St. Paul plume-type material along the SEIR with normal MORB basalts and the discovery of a specific mantle signature below the RTJ will help identify the major components in the mantle beneath the Indian Ocean.

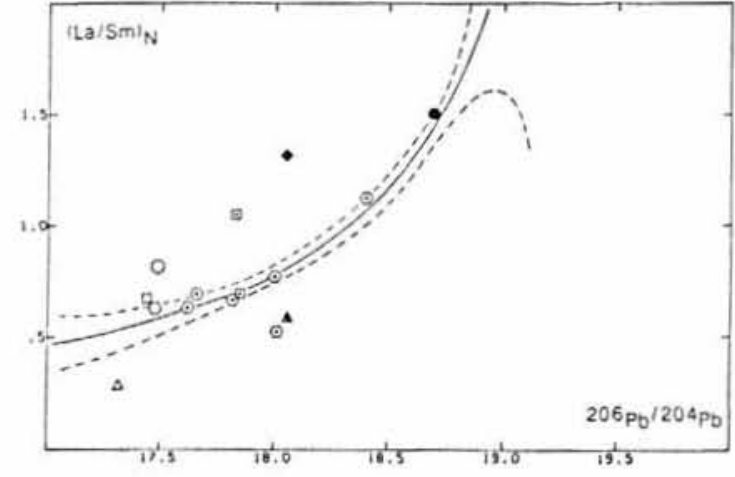

Figure 5

Chondrite-normalized REE patterns for the different groups of samples.

\section{Mixing processes along the South-East Indian Ridge}

Schilling [27] has recently shown that width of the geochemical anomaly associated with hot spots along the Mid-Atlantic Ridge decreases monotonically with the hot spot distance to the ridge, or somewhat equivalently, with the age of the oceanic floor underlying the active volcanic center. The distance of St. Paul to the ridge is not unambiguously defined as this island rests almost perfectly on the trace of a fracture zone, but does not exceed $50 \mathrm{~km}$. Such a value associated with the $300-500 \mathrm{~km}$ half-width of the hot spot halo on the SEIR places St. Paul on the Schilling's trend in spite of the unusual geochemical characteristics of this area; The model of mantle plumes deflected by migrating ridges which this author uses to explain this relationship may well; be of quite general relevance.

The correlation obtained on lead isotopes and the variations of the $(\mathrm{La} / \mathrm{Sm})_{N}$ ratio can be interpreted as resulting from a binary mixing process between an OIB-type and a MORB-type component [28-30]. To test this hypothesis, a least-squares mixing hyperbola is calculated in a ${ }^{206} \mathrm{~Pb} /{ }^{204} \mathrm{~Pb}$ versus $(\mathrm{La} / \mathrm{Sm})_{\mathrm{N}}$ diagram (Fig. 6) which shows the largest spread in measured values. The method of Juteau et al. [31] which has been used for this calculation, emphasizes the position of the asymptotes and hence constrains the end-member values. If one removes sample 37-5, which was shown to present an anomalous REE pattern, the points from the SEIR define a single hyperbola within the error bars. The OIB end-member should have a ${ }^{206} \mathrm{~Pb} /{ }^{204} \mathrm{~Pb}$ ratio higher than the St. Paul value of 18.7 and lower than the asymptotic ratio of $19.5 \pm 0.3$. Similarly, the $(\mathrm{La} / \mathrm{Sm})_{\mathrm{N}}$ ratio of the MORBtype component should be less than the minimum value of 0.63 near the RTJ but exceeds the asymptotic ratio of $0.3 \pm 0.2$. Other plats have been tried which, due to small variations, give results consistent with the binary mixing hypothesis but more imprecise.

In a ${ }^{207} \mathrm{~Pb} /{ }^{204} \mathrm{~Pb}$ vs. ${ }^{206} \mathrm{~Pb} /{ }^{204} \mathrm{~Pb}$ diagram, the SEIR trend intersects the geochron at the same point as the ocean island basalt subarrays considered in the two-stage evolution model of Chase [6]. As for islands from the Indian Ocean (Réunion, Kerguelen), the slope of the SEIR sub- 
array is higher and the intercept is lower than for the islands of the MAPT. Two conclusions can be drawn from this property : (1) each trend correspond to a quasi-binary micture between a radiogenic and a non-radiogenic endmember, and (2) the non-radiogenic component, presumably of the normal MORB type, is common to each mixture.

The Kerguelen-type characteristics of sample 37-6 are intriguing as this ridge segment is much remote from the Kerguelen island $(1000 \mathrm{~km})$. They suggest that, in spite of such a large distance and in the vicinity of a hot spot with different isotopic properties, some plume magmas erupted along the ridge may escape significant dilution by the normal MORB-type liquids. Scaling of movements in the mantle would suggest that depth and surface extension of the Kerguelen anomaly should not be of greatly different magnitude, hence placing the origin of the plume well within the lower mantle.

\section{The Rodriguez Triple Junction}

As previously noted by Frey et al. [32] and Price et al. [33], the basalts associated with the RTJ have high ${ }^{87} \mathrm{Sr} /{ }^{86} \mathrm{Sr}$ ratios coupled with LREE depletion. The isotope composition of $\mathrm{Sr}, \mathrm{Nd}$ and, to a lesser extent, $\mathrm{Pb}$ are homogeneous, except for sample 23-3 which is more depleted in LREE, $\mathrm{Sr}, \mathrm{Rb}$. As already pointed out, the RTJ basalts cannot represent the MORB-type and member of the SEIR pseudo-binary mixture as they have lower ${ }^{206} \mathrm{~Pb} /{ }^{204} \mathrm{~Pb}$ and higher ${ }^{87} \mathrm{Sr} /{ }^{86} \mathrm{Sr}$ ratios and lie above the ${ }^{207} \mathrm{~Pb} /{ }^{204} \mathrm{~Pb}$ vs. ${ }^{206} \mathrm{~Pb} /{ }^{204} \mathrm{~Pb}$ trend of the SEIR. The low ${ }^{206} \mathrm{~Pb} /{ }^{204} \mathrm{~Pb}$ and the LREE depletion of the RTJ samples

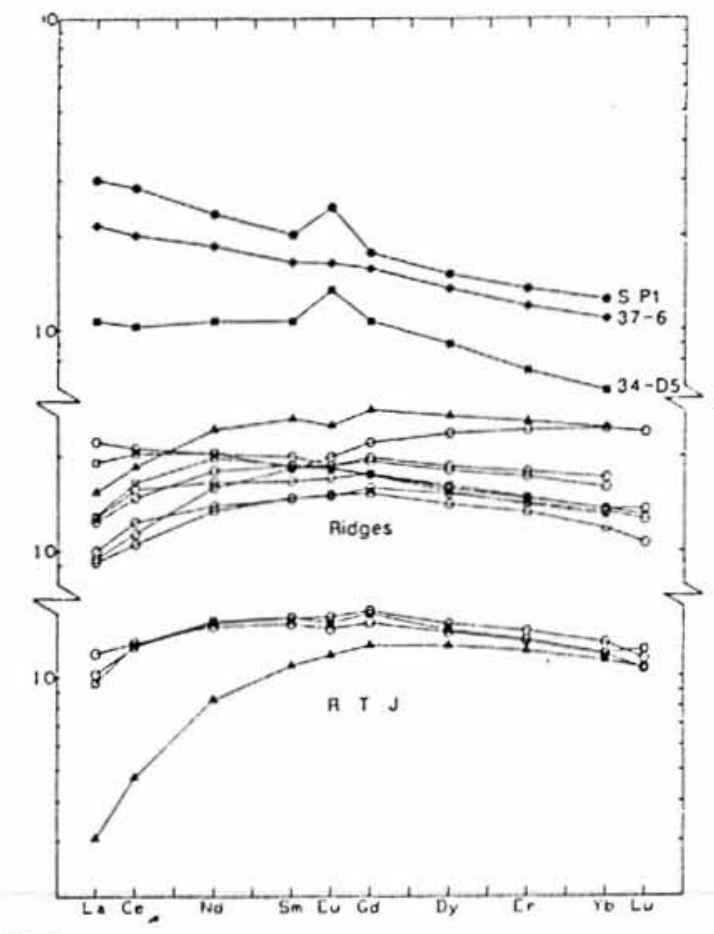

Figure 6

The least quares hyperbola and its $95 \%$ confidence surface calculated with St. Paul and five SEIR data points. Sanitite 37-6, southeast of St. Paul, has been omitted. preclude involvement of a plume component. They rather suggest similarly with one end-member of the Walvis Ridge basalts [34] and with the extremely anomalous sample 34-D5 of Hamelin and Allègre [15] from the SWIR.

$\mathrm{Yb}$ concentrations do not differ by more than $15 \%$ for all samples whereas the $(\mathrm{La} / \mathrm{Yb})_{\mathrm{N}}$ ratio changes by almost a factor 4. If different degrees of partial melting of a single peridotitic source were the cause of different REE patterns, this would indicate some sort of buffering of the HREE concentrations. Such a buffering could be achieved by minerals left in the residue, either few percent of garnet or a more substantial proportion of clinopyroxene.

The REE heterogeneities underneath the RTJ have to be recent : the total variation of the ${ }^{143} \mathrm{Nd} /{ }^{144} \mathrm{Nd}$ ratio at the RTJ is less than what the most extreme ${ }^{147} \mathrm{Sm} /{ }^{144} \mathrm{Nd}$ difference would produce in $10 \mathrm{Ma}$ by radioactive decay.

\section{Heterogeneities in the Indian Ocean Mantle}

The geochemistry of the present basalts requires that the mantle beneath the RTJ and the SEIR involves at least three components, a conclusion which is readily extended to most of the Indian Ocean and South Atlantic [8,15,34]. In a comprehensive plot of the $\mathrm{Pb}, \mathrm{Sr}$ and, $\mathrm{Nd}$ isotopic data on basalts from these regions, we have selected on a rather subjective basis three possible extreme components labelled DM for the MORB-type depleted mantle, EM for the OIB-type enriched mantle, and RC for the 34-D5-like end-member respectively (Tab. 2 and Fig. 2, $3,7)$. This selection has been guided by the requirement that, with few exceptions, the points representative of the samples should fall inside a triangle, either linear or curvilinear depending on the coordinates, determined by the three end-members.

As pointed out by Davies [7], the alignment of the OIB subarrays in $\mathrm{Pb}-\mathrm{Pb}$ diagrams, which now extends to the SEIR, and their convergence towards nearly the same point [6] is unexpected in a three-component mantle. A preliminary reduction of the degrees of freedom from three to two must take place prior to the late phase of binary mixing and eruption. In all the isotopic plats, a fairly general process may be envisioned if variable proportions of RC component are homogeneously mixed with both the EM and the DM component :

Table 2

Isotope composition and $(\mathrm{La} / \mathrm{Sm})_{N}$ value of the suggested three end-members

\begin{tabular}{|llll|}
\hline \multicolumn{1}{|c}{ Component } & \multicolumn{1}{c}{ DM } & \multicolumn{1}{c|}{ EM } & RC \\
\hline${ }^{87} \mathrm{Sr} /{ }^{86} \mathrm{Sr}$ & 0.7025 & 0.7035 & 0.7055 \\
${ }^{143} \mathrm{Nd} /{ }^{\mathrm{T} 144} \mathrm{Nd}$ & 0.5132 & 0.5128 & 0.5123 \\
${ }^{206} \mathrm{~Pb} /{ }^{204} \mathrm{~Pb}$ & 17.75 & 20.5 & 16.5 \\
${ }^{207} \mathrm{~Pb} /{ }^{204} \mathrm{~Pb}$ & 15.39 & 15.65 & 15.52 \\
${ }^{208} \mathrm{~Pb} /{ }^{204} \mathrm{~Pb}$ & 37 & 40 & 37.5 \\
$(\mathrm{La} / \mathrm{Sm})_{\mathrm{N}}$ & 0.3 & 2 & $?$ \\
\hline
\end{tabular}



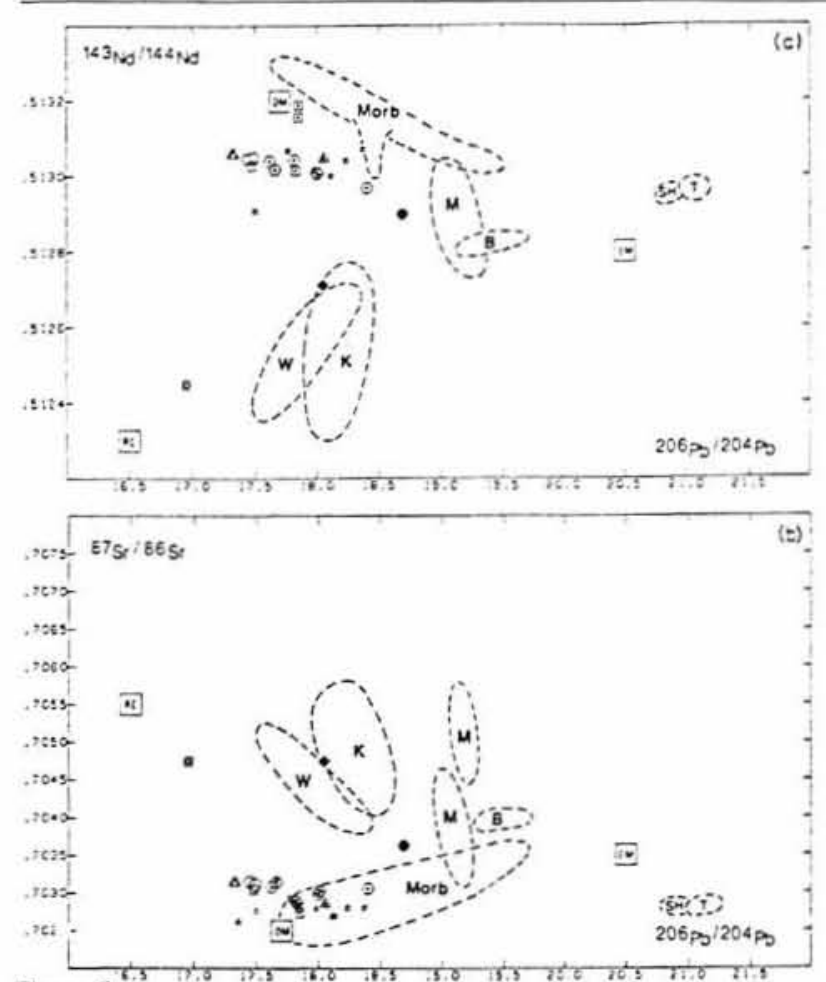

Figure 7

Comprehensive plots of published and present isotopic data from the Dupal anomaly area. Large open squares represent the three suggested end-members of the local mantle: $D M=$ depleted mantle, $E M=$ enricied mantle, $R C=$ recycled component. See Fig. 2 for symbols, Table 2 and text for end-member description.

- The radiogenic component of the OIB considered by Chase [6] and the SEIR would result from the mixing of commensurate bu variable proportions of EM and RC. The lower the slope in the ${ }^{207} \mathrm{~Pb} /{ }^{206} \mathrm{~Pb}$ vs. ${ }^{206} \mathrm{~Pb} /{ }^{204} \mathrm{~Pb}$ diagram, the more diluted the $\mathrm{RC}$ in the $\mathrm{EM}$ component. The MORB-like component observed in the SEIR basalts is largely dominated by the DM component, which ensures convergence of the $\mathrm{Pb}-\mathrm{Pb}$ subarrays towards the mixing point.

- The RTJ basalts may be explained as a RC-DM mix with a more significant proportion of the RC component.

- In lead-lead diagrams, where binary mixing produce linear arrays, the Walvis Ridge data converge between the DM and RC components; in this case a well-mixed DM$\mathrm{RC}$ end-member is apparently added to EM component mixed with an unknown but small proportion of RC.

Underlying this approach is an assumption concerning the scale of isotopic heterogeneity within the mantle : pre-homogenization of the RC with both the DM and EM components is suggestive of small-scale homogeneity and large scale heterogeneity of the RC distribution within the mantle. An isolated group of islands or a limited segment of the ridge system is characterized by specific proportions of RC in each end-member of the quasi-binary mixture which is demanded by the isotope correlation diagrams. In contrast, distant islands reveal substantial isotopic variations, particularly in the apparent EM / RC proportion.

The assignment of each potential end-member to a particular mantle source is somewhat subjective as both their actual number and geochemical properties remains speculative. If the three end-member model (DM, EM, and RC) defined in Figures 2, 3 and 7 is accepted, the nature of the associated mantle source may be constrained with a variable degree of confidence :

- The depleted mantle source (DM) has the lowest ${ }^{87} \mathrm{Sr} /{ }^{86} \mathrm{Sr},{ }^{207} \mathrm{~Pb} /{ }^{204} \mathrm{~Pb},{ }^{208} \mathrm{~Pb} /{ }^{204} \mathrm{~Pb},(\mathrm{La} / \mathrm{Yb})_{\mathrm{N}}$, and $\mathrm{Rb} / \mathrm{Sr}$ ratios, the highest ${ }^{143} \mathrm{Nd} /{ }^{144} \mathrm{Nd}$ and moderately low ${ }^{206} \mathrm{~Pb} /{ }^{204} \mathrm{~Pb}$-Table 2). It requires a long-term depletion in LILE and has been usually assigned to the residual upper mantle involved in many cycles of melt extraction [35-37]. N-type ("normal") MORBs derive predominantly from this source which may represent the refractory matrix of the upper part of the convecting mantle.

- The enriched mantle source (EM) has the most radiogenic lead and the highest $(\mathrm{La} / \mathrm{Yb})_{\mathrm{N}}$ ratio, ${ }^{87} \mathrm{Sr} /{ }^{86} \mathrm{Sr}$ and ${ }^{143} \mathrm{Nd} /{ }^{144} \mathrm{Nd}$ being intermediate between $\mathrm{DM}$ and $\mathrm{RC}$ values. This component is representative of what is known collectively as the "plume-type" component and enters largely most oceanic island basalts. An end-member of the St. Helena or Tubuii type $\left({ }^{87} \mathrm{Sr} /{ }^{86} \mathrm{Sr}=0.7028\right.$; ${ }^{206} \mathrm{~Pb} /{ }^{204} \mathrm{~Pb}>20$ ) provides a better closure than an endmember with a higher ${ }^{87} \mathrm{Sr} /{ }^{86} \mathrm{Sr}(0.704-0.706)$ but lower ${ }^{206} \mathrm{~Pb} /{ }^{204} \mathrm{~Pb}(19.0-19.5)$ characteristic of Marquesas or Society islands [38,39]. Separation from a reservoir shared by MORBs and the correlative enrichment in LILE has taken place with a characteristic time of $1-2 \mathrm{Ga}$ which either reflects discrete geological events $[6,13,40]$ or the mean age of a series of events [41]. The EM source has been assigned to recycled ancient oceanic lithosphere with spherical emphasis on the LILE enriched oceanic crust [4-6]. This hydrothermally altered oceanic crust is expected to have a high $\mathrm{U} / \mathrm{Pb}$ ratio than the surrounding mantle [42,43]. Alternatively, the EM source has been considered to represent a rather primary mantle which the multiple stages of MORB producing melting [1,2]. This latter point of view has been lent support by rare has isotope compositions indicative of little outgassing in some OIBs $[44,45]$ but conflicts with ${ }^{206} \mathrm{~Pb} /{ }^{204} \mathrm{~Pb}$ and ${ }^{207} \mathrm{~Pb} /{ }^{204} \mathrm{~Pb}$ ratios which are largely off the geochron. In both cases, the EM source lies beneath the DM source and its association with hot spots suggests that it is located at a deep mantle level. Other assumptions such as metasomatism [34] or sampling of an ancient continental lithospheric keel [46] are presently somewhat less constrained by geochemical data.

- The RC end-member may be characterized by extremely low ${ }^{206} \mathrm{~Pb} /{ }^{204} \mathrm{~Pb}$ ratios coexisting with low ${ }^{143} \mathrm{Nd} /{ }^{144} \mathrm{Nd}$ but intermediate to high ${ }^{207} \mathrm{~Pb} /{ }^{204} \mathrm{~Pb}$, and ${ }^{87} \mathrm{Sr} /{ }^{86} \mathrm{Sr}$ values. Whatever particular mantle component is thought to be responsible for the properties of this endmember, the question of why its occurrence is apparently restricted to the Indian Ocean will have to be addressed in the future. The chance that this component has been simply overlooked in other areas is probably rather high. Its unique properties seem to reflect a long term evolution in low $\mu$, low $\mathrm{Sm} / \mathrm{Nd}$, and high $\mathrm{Rb} / \mathrm{Sr}$ source which is indeed consistent with the trace element content of basalts which are most enriched in this component. For the 
sample 34-D5 itself, Hamelin and Allègre [15] consider several hypotheses but do not come up with definitive conclusions. One may first argue that this component has a few geochemical characteristics similar to those of a hypothetic primitive mantle (Tab. 1) especially if one allows for a substantial uncertainty in the Bulk Earth values $[7,47]$. However, the position of the presumed RC endmember is far left of the lead geochron and, for secondary isochrons which would converge towards the intersection of the oceanic island subarrays, in a "forbidden" par of the ${ }^{206} \mathrm{~Pb} /{ }^{204} \mathrm{~Pb}-{ }^{207} \mathrm{~Pb} /{ }^{204} \mathrm{~Pb}$ diagram. It is our contention that the present geochemical characteristics are easier to reconcile with contamination by old recycled sediments enriched in LREE and $\mathrm{Rb}$ relative to $\mathrm{Sr}$. The inferred lower $\mu$ value does not fir normal detrital material of continental origin. A veneer of hydrothermal deposits and abyssal clays covers ridge flanks, where they are progressively buried under terrigenous sediments. The $\mathrm{U} / \mathrm{Pb}$ ratio of hydrothermal waters from the East Pacific Rise vents is almost zero as a result of seawater $\mathrm{U}$ uptake by and PB leaching from the oceanic crust $[48,49]$. Dasch [50] has shown that they present a lead isotope signature intermediate between those of MORBs and continental detritus whereas their $\mu$ value is certainly fairly low [51]. Abyssal sediments have also quite high $\mathrm{Th} / \mathrm{U}$ ratios [52] which would be consistent with the rather high value inferred from the ${ }^{208} \mathrm{~Pb} /{ }^{204} \mathrm{~Pb}-{ }^{206} \mathrm{~Pb} /{ }^{204} \mathrm{~Pb}$ diagram. Their lower stratigraphic position at the top of the basaltic layer makes likely that part of them survive scraping or underplating along convergent boundaries and are subducted to the mantle, thereby giving rise to a subordinate but widespread component of the basalt sourcc.

\section{Implications for mantle structure}

The three-component model which is presented here implies that no part of the mantle which behaves as a source for basalts is really pristine. If the anomalous isotopic properties of the Indian and South Atlantic Ocean basalts (the Dupal anomaly of Hart [9]) relates to a component of recycled sediments (RC), such a component must be present in close association with

- the normal MORB source under the Rodriguez Triple Junction, the South-East Indian and Walvis Ridges; in the latter case, homogenization of the two components took place prior to mixing with EM-type melts;
- the enriched mantle source which produces most OIBs; homogenization with variable proportions of RC before interaction with the normal MORB source or melts is implicit in the assumed convergence of lead isotope subarrays for oceanic islands $[6,9]$.

Finally, it is worth stressing that the RTJ, in contrast with the Azores [30], Bouvet [53], Galapagos [54], and Afar [55] triple junctions, is not associated with a hot spot nor with any appreciable $\mathrm{OIB}$ geochemical signature in basalts. Whether the presence of the RC component in the source has a geophysical role in determining the position of this triple junction, just as could be the case for hot spots [12], is largely speculative at the moment but probably will deserve further attention.

\section{CONCLUSIONS}

This study of samples dredged in the center of the Dupal anomaly leads to a few major points :

- The South-East Indian Ridge basalts may be accounted for by a binary mixing between an Indian MORB and an $\mathrm{OIB}$ end-member. Influence of the latter component, associated with the St. Paul hot spot, is still substantial $400 \mathrm{~km}$ northwest of the island.

- Basalts from the Rodriguez Triple Junction are isotopically homogeneous and distinct from the SEIR MORBs. They are likely produced by a multistage process.

- The source of SEIR and RTJ MORBs must involve variable proportions of a component which is tentatively assigned to recycled ancient hydrothermal and abyssal sediments.

\section{Aknowledgements}

We thank the Captain and crew of the R/V Marion Dufresne and R/V Jean Charcot, J.Y. Roger for discussion and sample localization, F. Albarède for help in preparation and improvements of the manuscript, J.C. Demange for mass spectrometer maintenance.

Review of the manuscript by F.A. Frey, P. Vidal and A. Zindler gas been appreciated. 


\section{REFERENCES}

[1] Schilling J.G., 1973. Iceland mantle plume : geochemical study of Reykjanes Ridge. Nature 242. 565-57

[2] Wasserburg G.J. and DePaolo D.J., 1977. Models of earth struc ture inferred from neodymium and strontium isotopic abundances. Proc. Natl. Acad. Sci. U.S.A. 76, 3594-3598.

[3] Morris J.D. and Hart S.R., 1983. Isotopic and incompatible element constraints on the genesis of arc volcanics from Cold Bay and Amak Island, Aleutians, and implications for mantle structure. Geochim Cosmochim. Acta 47, 2015-2030.

[4] Zindler A., Staudigel H. and Batiza R., 1984. Isotope and trace element geochemistry of young pacific seamounts : implications for the scale of upper mantle heterogeneity. Earth Planet. Sci. Lett. 70. 175-195. [5] Hofmann A.W. and White W.M., 1980. The role of subducted oceanic crust in mantle evolution. Carnegie Inst. Washington Yearb. 79. 477-483.

[6] Chase C.G., 1981. Oceanic island lead: two-stage histories and mantle evolution. Earth Planet. Sci. Lett. 52. 277-284.

[7] Davies G.F., 1984. Geophysical and isotopic constraints on mantle convection : an interim synthesis. J. Geophys. Res., 89. 6017-6040.

[8] Dupré B. and Allègre C.J., 1983. Pb-Sr variation in Indian Ocean basalts and mixing phenomena. Nature, 303, 142-146.

[9] Hart S.R., 1984. A large-scale isotope anomaly in the Southern Hemisphere mantle. Nature, 309, 753-757.

[10] Tapscott C., Patriat P., Fischer R.L., Sclater J.G., Hoskins H. and Parsons B., 1980. The Indian Ocean Triple Junction. J. geophys. Res., 85, 4723-4739.

[11] Schlich R., 1982. The Indian Ocean : aseismic ridges, spreading centers and oceanic basins, In: The ocean Basins and Margins, A.E.M. Nairn and F.G. Stehli, eds., pp. 51-148.

[12] Hofmann A.W. and Hart S.R., 1978. Anassessment of local and regional isotopic equilibrium in the mantle. Earth Planet. Sci. Lett. 38, 44-62. [13] Tatsumoto M., 1978. Isotopic composition of lead in oceanic basal and its implication to mantle evolution. Earth Planet Sci. Lett. 38, 63-87.

[14] Schlich R., Munschy M., Marthelot J.M., Royer J.Y. and Schaming, 1986. Campagne du N.O. Jean Charcot dans l'océan Indien : Point Triple de Rodriguez. Bull.Soc. Geol. Fr., in press. 1986.

[15] Hamelin B. and Allègre C.J., 1985. Large-scale regional units in the depleted upper mantle revealed by an isotope study of the South-West Indian Ridge. Nature, 315, 196-199.

[16] Alibert C., Michard A. and Albarède F., 1983. The transition from alkali basalts to kimberlites: isotope and trace element evidence from melilitites. Contrib. Mineral. Petrol., 82, 176-186.

[17] Michard A., Gurrier P., Soudan M. and Albarède F., 1985. Nd isotopes in French Phanerozoic shales: external vs. internal aspects of crustal evolution, Geochim. Cosmochim. Acta, 49, 601-610, 1985.

[18] Manhes G., Minster J.F. and Allegre C.J., 1978. Comparative uranium-thorium-lead and rubidium-strontium of St. Severin amphoterite : consequences for early solar system chronology. Earth Planet. Sci. Lett. 39, 14-24.

[19] Le Roex A.P., Dick H.J.B., Erlank A.J., Reid A.M., Frey F.A. and Hart S.R., 1983. Geochemistry, miner(alogy and petrogenesis of lavas erupted along the Southwest Indian Ridge between the Bouve Triple Junction and 11 degrees east, J. Petrol. 24, 267-318.

[20] O'Nions R.K. and Pankhurst R.J., 1974. Petrogenetic significance of isotope and trace element variations in volcanics from the MidAtlantic. J. Petrol., 15, 603-634.

[21] ${ }_{143}$ 'Nipns R.K., Hamilton P.J. and Evensen N.M., 1977. Variation in ${ }^{43} \mathrm{Nd} /{ }^{44} \mathrm{Nd}$ and ${ }^{87} \mathrm{Sr} /{ }^{86} \mathrm{Sr}$ ratios in oceanic basalts. Earth Planet. Sci. Lett. 34, 13-22.

[22] Dosso L. and Murphy V.R. 1980. A Nd isotophic study of the Kerguelen islands : inferences on enriched oceanic mantle sources. Earth Planet. Sci. Lett. 48, 268-276.

[23] Hart S.R., 1976. LIL-element geochemistry, Leg 34 basalts, DSDP Leg 34. in : Initial Reports of the Deep Sea Drilling Project. Vol. 34. pp. 763-768. U.S. Government Printing Office, Washington, D.C.

[24] Cohen R.S. and O'Nions R.K., 1982. The lead, neodymium and strontium isotopic structure of ocean ridge basalts_. Petrol. 23, 299-334, 1982.

[25] White W.M. and B. Dupré. 1984. Isotope geochemistry of the mantle beneath the Indian Ocean (Abstract). EOS Trans. Am. Geophys. Union 65, 1139.

[26] Dosso L., Vidal P., Cantagrel J.M., Lemeyre J., Marot A. and Zimine S., 1979. "Kerguelen : continental fragment or oceanic island ?" : petrology and isotopic geochemistry evidence. Earth Planet. Sci. Lett. 43, 46-60.

[27] Schilling J.G., 1985. Upper mantle heterogeneities and dynamics. Nature, 314, 62-67.

[28] Hart S.R., Schilling J.G. and Powell J.L.. 1973. Basalts from lceland and along the Reykjanes Ridge : Sr isotope geochemistry, Nature, Phys. Sci., 246, 104.

[29] Sun S.S., Nesbitt R.W. and Sharaskin A.Y., 1979. Geochemical characteristics of Mid-Ocean Ridge basalts. Earth Planet. Sci. Lett., 44, 119-138.

[30] White W.M. and Schilling J.G., 1978. The nature and origin of geochemical variation in Mid-Atlantic Ridge basalts from central North Atlantic. Geochim. Cosmochim. Acta 42, 1501-1516.
[31] Juteau M., Michard A. and Albarède F., 1986. The Pb-Sr-Nd isotope geochemistry of recent Circum-Mediterranean granites. Contrib. Mineral. Petrol., in press.

[32] Frey F.A., Dickey J.S., Thompson Jr., G., Bryan W.B. and Davies H., 1980. Evidence for heterogeneous primary MORB and mantle sources. NW Indian Ocean, Contrib. Mineral. Petrol. 74, 387-402.

[33] Price R.C., Sneeringer M.R. and Frey F.A., 1982. Geochemistry of basalts from the West Indian Triple Junction $\left(25^{\circ} \mathrm{S}, 70^{\circ} \mathrm{E}\right)$ (abstract) EOS, Am. Geophys. Union 63, 473.

34] Richardson S.H., Erlank A.J., Duncan A.R. and Reid D.L. 1982. Correlated $\mathrm{Nd}, \mathrm{Sr}$ and $\mathrm{Pb}$ isotope variation in Walvis Ridge basalts and implications for the evolution fo their mantle source, Earth Planet. Sci. Lett. 59, 327-342.

[35] Gast P.W., 1968. Trace element fractionation and the origin of tholeiitic and alkaline magma types. Geochim. Cosmochim. Acta, 32, 1057-1086, 1968

[36] Sun S.S., Tatsumoto M. and Schilling J.G., 1975. Mantle plume mixing along the Reykjanes Ridge axis : lead isotopic evidence, Science $190,143-147$.

[37] O'Nions R.K., Evensen N.M. and Hamilton P.J., 1979. Geochemical modelling of mantle differentiation and crustal growth, J. Geophys. Res., 84, 6091-6101.

38] White W.M. and Hoffmann A.W., 1982. Sr and Nd isotope geochemistry of oceanic basalts and mantle evolution. Nature, 286, 821825.

[39] Vidal P., Chauvel C. and Brousse R., 1984. Large mantle heterogeneity beneath French Polynesia, Nature, 307, 536-538.

[40] Sun S.-S., 1980. lead isotopic study of young volcanic rocks from mid-ocean-ridges, ocean islands and island arcs. Philos. Trans. R. Soc. London, Ser.A, 297, 409-445.

[41] Allègre C.J., Brevart O., Dupré B. and Minster J.F., 1980. Isotopic and chemical effects produced in a continuously differentiating convecting earth mantle. hilos. Trans. R. Soc. London, Ser., A 297, 447-477. [42] Hart S.R. and Staudigel H., 1982. The control of alkalies and uranium in sea water by ocean crust alteration. Earth Planet. Sci. Lett. $58,202-212$

[43] Michart A., Albarède F., Michard G., Minster J.F. and Charlou J., 1983. Rare-earth elements and uranium in high temperature solutions from East Pacific Rise hydrothermal vent field $\left(13^{\circ} \mathrm{N}\right)$. Nature, 303, 795 797.

[44] Kurz M.D., Jenkins W.J. and Hart S.R., 1982. Helium isotopic systematics of oceanic islands and mantle heterogeneity. Nature, 297, 43-47.

[45] Allègre C.J., Staudacher T., Sarda P. and Kurz M., 1983. Con straints on evolution of Earth's mantle from rare gas systematics. Nature. 303, $762-766$.

[46] McKenzie D. and O'Nions R.K., 1983. Mantle reservoirs and ocean island basalts, Nature, 301, 229-231.

[47] White W.M., 1985. Sources of oceanic basalts: Radiogenic isotopic evidence. Geology, 13, 115-118.

[48] Chen J.H., Wasserburg G.J., Von Dam K.L. and Edmond J.M. 1984. $\mathrm{Pb}$. $\mathrm{U}$ an $\mathrm{Th}$ in hot springs on the East Pacific Rise at $21^{\circ} \mathrm{N}$ and Guaymas Basin, Golf of California (abstract), EOS. Am. Geophys. Union, 64,724 .

[49] Michard A. and Albarède F., 1985. Hydrothermal uranium uptake at ridge crest, Nature, 317, 244-246.

[50] Dasch E.J., 1981. Lead isotopic composition of metalliferous sediments from the Nazca plate, in: Nazca Plate: Crustal Formation and Andean Convergence, L.D. Kulm, J. Dymond, E.J. Dasch and D.M. Hussong, eds., pp. 199-210.

[51] Unruh M. and Tatsumoto M., 1976. Lead isotopic composition and uranium, thirum and lead concentrations in sediments and basalts from the Nazca plate in Initial Reports of the Deep Sea Drilling project, Vol. 34. pp. 341-347, U.S. Government Printing Office, Washington. D.C.

[52] Cochran, J.K. and Krishnaswami S.K., 1980. Radium, Thorium, uranium, and ${ }^{210} \mathrm{~Pb}$ in deep-sea sediments and sediment pore waters from the North Equatorial Pacific, Am. J. Sci. 280, 849-889.

[53] Dickey J.S., Frey F.A., Hart S.R., Watson E.B. and Thompson G., 1977. Geochemistry and petrology and dredged basalts from the Bouvet Triple Junction, South Atlantic, Geochim. Cosmochim. Acta, 41, 1105-1118.

[54] White W.M. and Hofmann A.W., 1978. Geochemistry of the Galapagos Islands: implications for mantle dynamics and evolution, Carnegie Inst. Washington Yearb. 77, 596-606.

[55] Betton P.J. and Civetta L., 1984. Strontium and neodymium isotopic evidence for the heterogeneous nature and development of the mantle beneath Afar (Ethiopia), Earth Planet. Sci. Lett. 71, 59-70.

[56] Dupré B. and Allègre C.-J., 1980. Pb-Sr-Nd isotopic correlation and the chemistry of the North Atlantic mantle, Nature, 286, 17-22.

[57] Cohen R.S., Evenson N.M., Hamilton P.J. and O'Nions R.K. 1980. U.Pb. Sr-Nd and $\mathrm{Rb}-\mathrm{Sr}$ systematics of mid-ocean ridge basalts glasses. Nature, 283, 149-153.

[58] Oversby V.M., 1972. Genetic relations among the volcanic rocls of Reunion : chemical and lead isotopic evidence. Geochim. Cosmochim. Acta, 36, 1167-1179. 